\title{
Hay không hay nhất
}

(2021)

\author{
Khúc Văn Quý
}

January 1, 2021

Preprint DOI: https://osf.io/rwzeh

Pháo hoa giòn giã cho ta biết

Một năm hay nhất đã bắt đầu

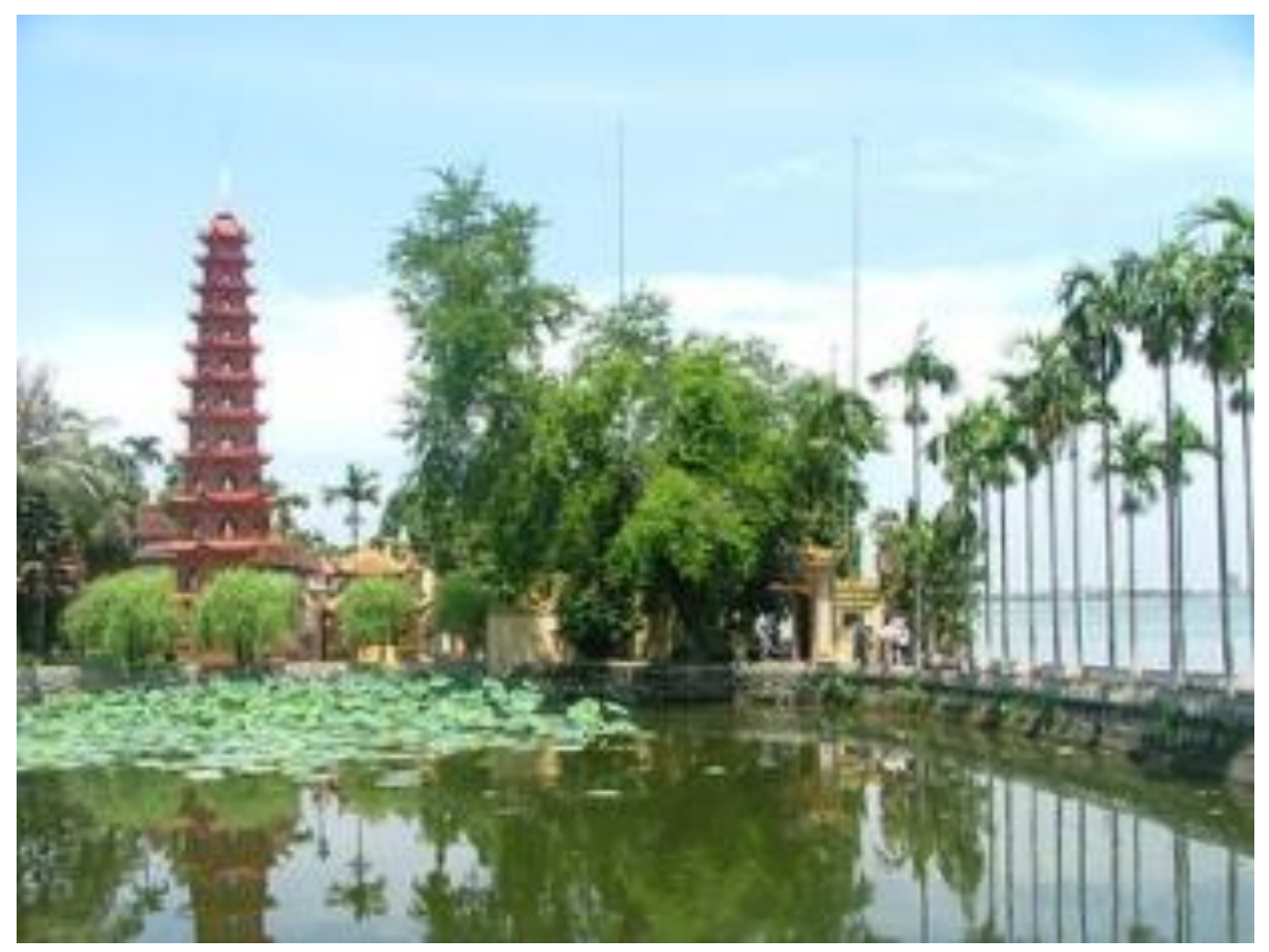

Trấn Quốc pagoda¹/source: https://vi.wikipedia.org

\footnotetext{
${ }^{1}$ Chùa Trấn Quốc là ngôi chùa lâu đời nhất ở Hà Nội, nằm trên một hòn đảo nhỏ ở Phía Đông Hồ Tây (quận Tây Hồ), Việt Nam
} 